УДК 614.84 : 368.11] (438) “19”

\author{
Bednaruk Waldemar \\ Dr. hab., profesor nadzwyczajny, \\ Katedra Historii Ustroju i Prawa, \\ Katolicki Uniwersytet Lubelski Jana Pawła II, \\ Lublin, Polska, \\ wbednaruk@kul.lublin.pl
}

\title{
CZYNNIKI WPLYWAJĄCE NA ILOŚĆ POŻARÓW W POLSCE CZASÓW WIELKIEGO KRYZYSU GOSPODARCZEGO
}

Celem artykułu jest zbadanie czynników, które wpłynęły na sytuację pożarową w Polsce w okresie międzywojennym. Oprócz czynników naturalnych i technicznych, których znaczenie malało wraz z rozwojem nowych technologii wznoszenia budowli, ogromny i z czasem coraz większy wpływ na kwestię ilości wybuchających pożarów miała działalność człowieka. $Z$ jednej strony samych ubezpieczonych, którzy powodowali znaczną ilość pożarów, z drugiej zaś zakładów ubezpieczeniowych, kreujących poprzez swoją politykę określone zachowania właścicieli polis ubezpieczeniowych. Polityka tego ubezpieczyciela w połączeniu $\mathrm{z}$ aktualną sytuacją gospodarczą miała największy wpływ na zachowania ubezpieczonych w całym okresie istnienia Polski międzywojennej. Pytaniem otwartym pozostaje kwestia na ile świadomie ta polityka była kształtowana. Sytuacja gospodarcza kraju nie mogła pozostać i nie pozostała bez wpływu na rynek ubezpieczeń. $Z$ jednej strony ubezpieczyciele zaczęli się borykać z wielką liczbą obywateli, którzy nie byli w stanie podołać obowiązkowi opłacania składek $\mathrm{z}$ tytułu przymusowych ubezpieczeń, o dobrowolnych już nie wspominając. $Z$ drugiej zaś brak tego czynnika zabezpieczającego przed wyłudzeniami w postaci wysokiej inflacji nie chronił już zakładu tak jak jeszcze kilka lat wcześniej. Czynnik ludzki wywierał największy wpływ na ilość pożarów w okresie wielkiego kryzysu gospodarczego. Głównymi metodami badań była historyczna, statystyczna metoda i metoda analizy.

Słowa kluczowe: Polska w okresie międzywojennym, ubezpieczenia, rynek nieruchomości, Powszechny Zakład Ubezpieczeń Wzajemnych.

Беднарук Вальдемар, доктор габілітований, профессор, кафедра історії політики та права, Люблінський католиџький університет Іоанна Павла II, Люблін, Польща

Фактори, що впливають на кількість пожеж у Польщі під час Великої економічної кризи

Метою статті є дослідження факторів, що вплинули на пожежну ситуацію у Польщі в міжвоєнний період. Окрім природних і технічних факторів, значення 
яких зменшилася 3 розвитком нових технологій зведення будівлі, величезна i подальша діяльність людини все більше впливає на питання про кількість вибухонебезпечних пожеж. 3 одного боку, самі застраховані, які викликали значну кількість пожеж, а з іншого - страхові компанії, створюючи за допомогою своєї політики конкретну поведінку власників страхових полісів. Політика страхування в поєднанні з поточною економічною ситуацією мала найбільший вплив на поведінку страхувальника протягом усього існування міжвоєнної Польщі. Відкритим залишається питання, наскільки усвідомлено ця політика була сформованою. Економічна ситуація в країні не могла не впливати на страховий ринок. 3 одного боку, страховики почали боротися 3 великою кількістю громадян, які не могли здійснювати обов'язкові виплати за примусове страхування, не кажучи вже про добровільність. 3 іншого боку, відсутність фактора, що запобігав би втратам від високої інфляції, не захищав вже установу так, як кілька років раніше. Людський фактор мав найбільший вплив на кількість пожеж під час великої економічної кризи. Головними методами дослідження стали історичний, статистичний та метод аналізу.

Ключові слова: Польща в міжвоєнний період, страхування, ринок нерухомості, Універсальний інститут взаємного страхування.

Bednaruk Waldemar, Dr. hab., Associate Professor, Department of History of Law and Law, The John Paul II Catholic University of Lublin, Lublin, Poland

\section{Factors affecting the amount of fires in Poland during the Great Economic Crisis}

The purpose of the article is to study the factors that influenced the fire situation in Poland during the interwar period. In addition to the natural and technical factors, the importance of which has diminished with the development of new building technologies, huge and further human activities are increasingly affecting the issue of the explosive fires number. On the one hand, the insured people themselves caused a significant number of fires, and, on the other - these were insurance companies, using their policies to create a concrete behavior of the insurance policyholders. The policy of insurance combined with the current economic situation had the greatest impact on the policyholder's behavior throughout the period of interwar Poland existence. There still remains the question how well the policy has been formed. The economic situation in the country could not but affect the insurance market. On the one hand, insurers began to struggle with a large number of citizens not been able to enforce compulsory insurance payments, let alone voluntary insurance. On the other hand, the absence of the factor preventing losses caused by high inflation did not protect the institution as it had been a couple of years before. The human factor had the greatest impact on the number of fires during the major economic crisis. The main methods of research were historical, statistical, and analysis methods. 
Key words: Poland in the interwar period, insurance, real estate market, Universal Mutual Insurance Institute.

Беднарук Вальдемар, доктор габилитованый, профессор, кафедра истории политики и права, Люблинский католический университет Иоанна Павла II, Люблин, Польша

Факторы, влияющие на количество пожаров В Полыше во время

\section{Великого экономического кризиса}

Целью статьи является исследование факторов, повлиявших на пожарную ситуацию в Польше в межвоенный период. Кроме природных и технических факторов, значение которых уменьшилось с развитием новых технологий возведения строений, огромная и дальнейшая деятельность человека все больше влияет на вопрос о количестве взрывоопасных пожаров. С одной стороны, сами застрахованные, которые вызвали значительное количество пожаров, а с другой - страховые компании, создавая с помощью своей политики конкретное поведение страхователей. Политика страхования в сочетании с текущей экономической ситуацией имела наибольшее влияние на поведение страхователя в течение всего существования межвоенной Польши. Открытым остается вопрос, насколько осознанно эта политика была сформированной. Экономическая ситуация в стране не могла не влиять на страховой рынок. С одной стороны, страховщики начали бороться с большим количеством граждан, которые не могли осуществлять обязательные выплаты за принудительное страхование, не говоря уже о добровольности. С другой стороны, отсутствие фактора, предотвращало бы потери от высокой инфляции, не защищало уже учреждение так, как несколько лет раньше. Человеческий фактор имел наибольшее влияние на количество пожаров во время большого экономического кризиса. Главными методами исследования стали исторический, статистический и метод анализа.

Ключевые слова: Польша в межвоенный период, страхование, рынок недвижимости, Универсальный институт взаимного страхования.

Wprowadzenie. Oprócz czynników naturalnych, takich jak pogoda; technicznych wśród których warto wymienić jakość wykonania budynków, czy materiały (mniej lub bardziej palne) z których je zbudowano warto wymienić i te najbardziej zależne od woli ludzkiej oraz od działania samych osób zainteresowanych. Ten ostatni element jest szczególnie widoczny w czasach nam najbliższych, gdy na skutek upowszechnienia się instytucji ubezpieczeń majątkowych celowe niszczenie własnego majątku stało się źródłem dodatkowych zysków dla nieuczciwych osób.

Polska ze względu na swoją historię, położenie geograficzne oraz brak aspiracji kolonialnych nie należała do państw $\mathrm{z}$ bogatymi tradycjami 
ubezpieczeniowymi. W rzeczywistości na ziemiach polskich okresu przedrozbiorowego ubezpieczenia były mało znane i rzadko stosowane. W okresie zaborów polityka mocarstw rozbiorowych kształtowana była odmiennie, poczynając od systemu w znakomitej większości dobrowolnych ubezpieczeń w zaborze austriackim, poprzez obowiązkowe, ale bez istnienia państwowego monopolu w pruskim, aż po scentralizowane pod egidą rządu i również obligatoryjne w zakresie asekuracji od ognia w Rosji [16, s. 135].

Po odzyskaniu niepodległości w 1918 roku władze polskie zdecydowały się przyjąć i przeszczepić, początkowo tylko na terenie b. Królestwa Polskiego, a później na znakomitej większości obszaru państwa (poza Warszawą i terenem dawnego zaboru pruskiego) model rosyjski, w którym państwowy monopolista w postaci Towarzystwa Ubezpieczeń Wzajemnych stał się przymusowym ubezpieczycielem nieruchomości od ognia. I od tej pory, pomimo zmian nazwy publicznego ubezpieczyciela (od 1921 roku Polska Dyrekcja Ubezpieczeń Wzajemnych, a od 1927 Powszechny Zakład Ubezpieczeń Wzajemnych) i drobnych korekt w zakresie obowiązku ubezpieczeniowego, aż do końca istnienia II Rzeczypospolitej mieliśmy do czynienia z jednym dużym zakładem obsługującym znacznie powyżej $90 \%$ ubezpieczeń od ognia oraz grupą $\mathrm{z}$ reguły mniejszych ubezpieczycieli prywatnych, zajmujących się $\mathrm{w}$ większości pozostałymi działami ubezpieczeń [2, s. 83]. I to polityka tego ubezpieczyciela $\mathrm{w}$ połączeniu $\mathrm{z}$ aktualną sytuacją gospodarczą miała największy wpływ na zachowania ubezpieczonych $w$ całym okresie istnienia Polski międzywojennej. Dlatego też przeprowadzona analiza odnosi się właśnie do tego zakładu ubezpieczeń z pominięciem pozostałych ubezpieczycieli.

Statystyki pożarów $\mathbf{w}$ okresie przedkryzysowym. Dla lepszego zobrazowania zachodzących na rynku ubezpieczeń zjawisk należy z okresu tego wydzielić dwa niemal równej długości podokresy: pierwszy trwający od końca 1918 roku do połowy 1924 i drugi od połowy 1924 do początków 1930 roku.

$\mathrm{W}$ pierwszym z nich rodzące się z trudem państwo borykało się z ogromnymi problemami gospodarczymi, w tym również z wciąż przyspieszającą inflacją, która $\mathrm{w}$ 1923 roku przekształciła się w hiperinflację [1, s. 275]. Ta słaba kondycja polskiej gospodarki w połączeniu z ostrożną polityką ubezpieczycieli, którzy dopiero tworzyli zręby systemu ubezpieczeń na ziemiach polskich, nie skłaniały ubezpieczonych do podejmowania świadomych działań wymierzonych we własny majątek.

Widać to bardzo wyraźnie w statystykach publicznego ubezpieczyciela $\mathrm{z}$ tego podokresu. Liczba pożarów utrzymuje się wówczas na dość niskim pułapie, stąd koszty wypłaty odszkodowań na bezpiecznym poziomie w relacji do pozyskanych $\mathrm{z}$ tytułu składek kwot pozwalały na przetrwanie trudnych początków. Mając na względzie fakt, iż przed wojną i w czasie jej trwania tzw palność nieruchomości, czyli stosunek wypłacanych odszkodowań do pozyskanych sum z tytułu składek, wynosiła około $70 \%$ [3, s. 11 i 4, s. X], musimy uznać, iż po zakończeniu działań wojennych 
relacje te znacznie się poprawiły. W 1918 palność wyniosła 52\%, w 1919 roku $43 \%$, w 1920 roku - 41\%, w 1921 roku - 49,5\% [3, s. 11], ale już w 1922 roku $32,1 \%$, w 1923 roku tylko $22 \%$, zaś w 1924 odnotowano lekki wzrost - 30\% $[4$, s. X].

Przedstawione wyżej zjawisko malejącej palności ubezpieczonych przymusowo nieruchomości wynikało z szeregu połączonych ze sobą czynników. Po pierwsze z działań ubezpieczyciela, który nie nadążał za zmianami rynkowej wartości ubezpieczonych nieruchomości, które przez to były stale niedoszacowane, a więc ubezpieczone poniżej swojej rzeczywistej ceny. Pytaniem otwartym pozostaje kwestia na ile świadomie ta polityka była kształtowana. Nie skłaniała ona jednak właścicieli do podejmowania działań wymierzonych w swój majątek, gdyż uzyskane kwoty odszkodowań nie pokrywały poniesionych strat. $Z$ drugiej strony ubezpieczeni sami też nie dążyli do urealnienia szacunków ze względu na spodziewany wzrost składek z tego tytułu.

Jeśli do wyżej wskazanych czynników dodamy stosunkowo niską skuteczność realizacji obowiązku ubezpieczeniowego, wynikającą z unikania go przez właścicieli nieruchomości oraz stopniowo rosnącej, ale jeszcze niedostatecznej szczelności systemu po stronie zakładu. A gdy do tego uwzględnimy wysoką inflację, skutkującą błyskawiczną utratą wartości pieniądza, co niejednokrotnie prowadziło do ruiny poszkodowanych, gdyż pomiędzy okresem oszacowania wartości nieruchomości, a nastąpieniem szkody i następnie wypłatą odszkodowania mogło dojść do odzyskania jedynie drobnego ułamka aktualnej wartości ubezpieczonego majątku, to uzyskamy obraz bardzo trudnych relacji na rynku ubezpieczeń [16, s. 202].

Sytuacja diametralnie zmieniła się $\mathrm{w}$ drugim podokresie, czyli tuż po reformie walutowej premiera Władysława Grabskiego, dokonanej w kwietniu 1924 roku. Pozwoliła ona na zahamowanie inflacji, ustabilizowanie gospodarki i jej dynamiczny rozwój w następnych latach. Reforma ta miała też przemożny wpływ na rynek ubezpieczeń w naszym kraju. Niska inflacja pozwoliła na precyzyjne oszacowanie wartości ubezpieczanego majątku, który utrzymywał realną cenę przez szereg kolejnych lat. Uszczelnienie systemu pozwoliło na rozciągnięcie obowiązku ubezpieczenia na większą ilość nieruchomości, ułatwiały ten trend również zmiany $\mathrm{w}$ prawie, co w konsekwencji doprowadziło do obniżenia składki i zachęciło również najuboższych do zaprzestania unikania asekuracji.

Jednak te korzystne trendy spowodowały również większą opłacalność procederu wyłudzania odszkodowań. W warunkach niskiej inflacji nie zachodziły przeszkody widoczne tak wyraźnie we wcześniejszym podokresie. Stąd też powoli, ale stopniowo rośnie każdego roku palność nieruchomości, osiągając w poszczególnych latach wartości rzędu: w 1925 roku - 36,6\%, w 1936 roku - 37,2 \%, w 1927 roku już $50,4 \%$, w 1928 - 55,9\% i wreszcie w 1929 roku niebezpieczne dla płynności finansowej zakładu $72,2 \%$ [5, s. 13; 6, s. 13]. 


\section{ФАКТОРИ, ЩО ВПЛИВАЮТЬ НА КІЛЬКІСТЬ ПОЖЕЖ У ПОЛЬЩІ ПІД ЧАС ВЕЛИКОЇ ЕКОНОМІЧНОЇ КРИЗИ}

Co prawda zjawisko to mogłoby wyglądać jeszcze gorzej dla ubezpieczyciela, zaś statystyczne wzrosty w poszczególnych latach byłyby znacznie wyższe, gdyż liczba pożarów w tym podokresie i sum wypłacanych $\mathrm{z}$ tego tytułu rosły znacznie szybciej niż wynikałoby to $z$ analiz dotyczących palności, jednak fakt, iż jeszcze dynamiczniej powiększały się kwoty składek ściąganych od zobowiązanych właścicieli nieruchomości sprawil, że otrzymano takie, a nie inne wyniki.

Pożary w okresie wielkiego kryzysu. Wielki kryzys gospodarczy, zapoczątkowany w Stanach Zjednoczonych jesienią 1929 roku, do Polski dotarł z kilkumiesięcznym opóźnieniem w 1930 roku, ale pozostał też dłużej, bo o ile szacuje się, że Zachód wyszedł z niego w 1933 roku, to u nas ożywienie nastąpiło dopiero po 1935 roku. W niektórych jednak biedniejszych rejonach i gałęziach gospodarki jego skutki odczuwalne były aż do wybuchu II wojny światowej. Ogromne bezrobocie, spadek produkcji krajowej o połowę, bankrutujące zakłady przemysłowe i ubożejąca w szybkim tempie wieś, to główne objawy kryzysu na ziemiach polskich. Jednocześnie jednak rząd utrzymywał wysoki kurs złotego, nie chcąc ponownie dopuścić do zbyt wysokiej inflacji [1, s. 311].

Sytuacja gospodarcza kraju nie mogła pozostać i nie pozostała bez wpływu na rynek ubezpieczeń. $Z$ jednej strony ubezpieczyciele zaczęli się borykać z wielką liczbą obywateli, którzy nie byli w stanie podołać obowiązkowi opłacania składek z tytułu przymusowych ubezpieczeń, o dobrowolnych już nie wspominając. $Z$ drugiej zaś brak tego czynnika zabezpieczającego przed wyłudzeniami w postaci wysokiej inflacji nie chronił już zakładu tak jak jeszcze kilka lat wcześniej.

Położenie publicznego ubezpieczyciela u progu wielkiego kryzysu znacznie pogarszały słabe wyniki osiągnięte $\mathrm{W}$ roku poprzedzającym zapaść gospodarczą. W znacznym stopniu wpłynęły na to zjawisko pewne nazbyt śmiałe kroki kierownictwa zakładu, które poleciło w okresie prosperity przygotowanie i stopniowe wdrożenie w życie nowych norm szacunkowych i tabel składek, które po kilku latach rozwoju gospodarczego miały urealnić wartość ubezpieczanych nieruchomości, oraz pobieranych od tych nowych kwot sum należnych z tytułu składki.

Wspomniana operacja została zakończona z sukcesem w 1928 roku, dokonano wówczas znacznego doszacowania budowli, wzrosła ich wartość, odzwierciedlona w kwocie ubezpieczenia, oraz w należnych składkach, jednak zabieg ten nie przyniósł pełni spodziewanych zysków zakładowi, gdyż obok korzyści naraził też ubezpieczyciela na straty. Nowe normy, pozwalające na ubezpieczenie budowli na wyższą kwotę, czasem znacznie przekraczającą rzeczywistą jej wartość stały się pokusą nie do odparcia dla oszustów ubezpieczeniowych, co doskonale widać w skokowym wzroście palności budowli w dziale przymusowym następnego, czyli 1929 roku rozliczeniowego [5, s. 13].

Co gorsze poziom z ostatniego roku przedkryzysowego utrzymał się, a nawet nieco wzrósł do $72,6 \%$ w 1930 roku, następnego zaś do dramatycznych 73,7\%. 
Dopiero kiedy zakład zaczął ponosić znaczne szkody dostrzeżono zgubny wpływ tak wysokiego oszacowania majątków. To co miało być źródłem dodatkowych zysków stało się przyczyną kłopotów ubezpieczyciela i wymagało zdecydowanych działań z jego strony. W pierwszym rzędzie próbowano osłabić wpływ tego podstawowego czynnika poprzez masowe obniżanie wyceny wartości nieruchomości.

Jako przyczynę przeprowadzenia tej operacji podano duży spadek cen materiałów budowlanych, a szczególnie drewna, którego w budownictwie tego okresu wykorzystywano ogromne ilości. Drugim powodem zaś miała być ochrona przed spekulacyjnymi pożarami. W całym 1930 roku przeprowadzono w kraju 130 tys. kontroli szacunków nieruchomości, zaś w tych powiatach, gdzie dało się określić, iż spadek cen był w miarę jednolity wprowadzono ogólną obniżkę wartości określoną procentowo dla danego obszaru. Zabiegiem tym objęto 22 powiaty, a na ich obszarze 367 tys. nieruchomości. Dodatkowo, aby ułatwić płatnikom realizację obowiązku wprowadzono od tego roku możliwość opłacania składki w dwóch ratach, a nie jednej jak dotychczas [6, s. 9, s. 11-12].

Zastosowane środki zaradcze okazały się zbyt słabe, by przynieść satysfakcjonujące rezultaty, stąd w kolejnym 1931 roku dokonano od 1 stycznia obniżenia szacunków wartości w 34 powiatach o 10-20\%. Zaś od marca o $10 \%$ obniżono szacunki na wszystkich tych terenach, na których do tej pory nie dokonano tego zabiegu i raz jeszcze od lipca o $10 \% \mathrm{w}$ wybranych 30 powiatach. Jednocześnie wzmożono nacisk na uszczelnienie systemu. Próbowano przeciwdziałać wyłudzeniom poprzez nowe procedury szacowania szkód po pożarze, pilniejsze poszukiwanie przyczyn wystąpienia szkody, badając udział czynnika ludzkiego, a wreszcie wprost pod kątem znalezienia winnego. W końcu posunięto się i do tego, iż wyznaczono nagrodę $\mathrm{w}$ wysokości 500 złotych, co było wówczas znaczną sumę pieniędzy, za wskazanie podpalacza, oczywiście jeśli jego wina zostanie udowodniona, a on sam skazany [7, s. 9].

Wyniki analiz statystycznych wykazały $\mathrm{w}$ tym okresie jeszcze jeden niepokojący wskaźnik. Otóż stwierdzono, iż płonące nieruchomości są z reguły wyżej ubezpieczone od pozostałych i przeważnie powyżej swojej rzeczywistej wartości, co nie mogło być przypadkowe i znacznie pogarszało wyniki ubezpieczyciela. Tylko w samym 1931 roku ustalono, iż średnia suma ubezpieczenia płonącej budowli jest o 17 \% wyższa od średniej kwoty ubezpieczenia nieruchomości w ogóle. Różnice te w rozbiciu na trzy prowincje, $w$ jakich zazwyczaj prezentowano wyniki przedstawiały się następująco: najgorzej sytuacja wyglądała w województwach południowych, gdzie różnica pomiędzy wartością polisy spalonej budowli była o 68 \% wyższa od średniej sumy ubezpieczenia budowli w tym rejonie; nieco lepiej w województwach wschodnich, gdzie ta różnica wynosiła $32 \%$; zaś najlepiej sytuacja wyglądała w województwach centralnych, gdzie najwyraźniej oszuści nie operowali tak swobodnie, tam różnica była ujemna i wynosiła minus $6 \%$ [15, s. 17]. 
W kolejnych latach zakład przeznaczał duże środki na wspieranie policji ścigającej oszustów ubezpieczeniowych, a także walczącej z pożarami straży pożarnej oraz promował budownictwo z materiałów mniej podatnych na spalanie. Jednocześnie jednak nie zaniedbano działań mających zmniejszyć opłacalność przestępczego procederu - od 1932 roku uzależniono wypłatę odszkodowania od wielu czynników, takich jak odbudowa nieruchomości, terminowość prac budowlanych i regulowanie należnych składek. Odszkodowania wypłacano w ratach w miarę postępu prac nad odtworzeniem poprzedniego stanu nieruchomości. W dalszym ciągu również obniżano systematycznie szacunki o 10 do $40 \%$ w styczniu 1932 roku na całym obszarze kraju (poza dużymi miastami) i o $10 \%$ do $40 \%$ od 1 marca 1932 roku w stosunku do całego portfela ubezpieczeń [8, s. 8-9; 9, s. 19]

Podjęte kroki o charakterze nadzwyczajnym w połączeniu $\mathrm{z}$ wielką akcją uświadamiania społeczeństwa, jaką przeprowadzono w tych latach, by przekonać płatników, iż przestępczość ubezpieczeniowa bije we wszystkich, a nie tylko w sam zakład powoli i stopniowo zaczęły przynosić skutki. Kiedy do tego dodano bezwzględne środki wobec własnych pracowników, mające na celu utrudnienie ich współdziałania przy oszustwach mógł ubezpieczyciel z satysfakcją odnotować w 1933 roku, iż niekorzystny trend zagrażający płynności finansowej zakładu został zahamowany [9, s. 9-11].

Przejściowa stabilizacja, czy nawet nieznaczna poprawa kondycji, rynku asekuracji w ostatnich miesiącach 1932 i w całym 1933 roku nie skłoniła ubezpieczycieli do zaniechania polityki ostrożnych kroków. W dalszym ciągu, podążając za spadkiem cen materiałów budowlanych, obniżano kilkakrotnie wwybranych powiatach szacunki w poszczególnych działach ubezpieczeń od ognia. Jedna taka obniżka nastąpiła w lipcu 1933 i dwie: w styczniu i lipcu w 1934 roku. Były one już niższe (w granicach 10-20\%) i bardziej punktowo dokonywane. Publikowana okresowo mapa palności w poszczególnych powiatach pozwalała kierować ostrze stosowanych narzędzi na precyzyjniej określony cel [10, s. 12].

Wkrótce okazało się, iż przezorność w działaniu ubezpieczycieli była w pełni uzasadniona - kryzys gospodarczy bowiem jeszcze się nie skończył, gdy w latach 1933-34 spadły na kraj klęski żywiołowe: grad, a w następnym roku katastrofalna powódź, które na znacznych obszarach zrujnowały rolnictwo i poważnie nadszarpnęły budżety zakładów. Zakłady musiały $\mathrm{z}$ jednej strony pogodzić się ze stratami spowodowanymi nieopłaconymi składkami, z drugiej zaś wypłacić duże sumy z tytułu odszkodowania [10, s. 17]. Do tego palność budynków nie osiągnęła jeszcze satysfakcjonującego poziomu, dlatego kierując się aktualnymi cenami na rynku nieruchomości w poszczególnych powiatach, oraz pomocniczo mapami obrazującymi miejsca o najgorszych statystykach kontynuowano korekty szacunków wartości nieruchomości. W 1934 roku przeprowadzono jedną w lipcu, zaś w 1935 dwie: od 1 stycznia i od 1 lipca, za każdym razem o 10-20\%, przy czym w większości 
przypadków na tym najniższym poziomie, zaś w przypadku jednego miasta aż o $30 \%$ [11, s. 14-15].

Opisane wyżej metody przeciwdziałania nieuzasadnionym naturalnymi zjawiskami wzrostom sum wypłacanych odszkodowań z tytułu pożarów przyniosły oczekiwane rezultaty. Palność budowli obniżyła się do bezpiecznego poziomu stopniowo i z pewnymi zawirowaniami, poczynając od najgorszego w tym okresie roku 1931, w którym odnotowano szkody z tego tytułu na poziomie $73,7 \%$; poprzez $55,7 \%$ w 1932; 50,4 \% w 1933 roku; 63,6\% - w 1934 roku i $60 \%$ w 1935. Lata pokryzysowe, to już znaczny spadek palności do poziomu $50 \%$ i poniżej, co pozwoliło ubezpieczycielom odetchnąc od tych chudych lat, kiedy zakłady balansowały na krawędzi wypłacalności. Jednak te bolesne doświadczenia nauczyły branżę ubezpieczeń pewnej ostrożności i dojrzałości w podejmowaniu decyzji, mogących mieć wpływ na przyszłość. Stąd też nie zaniechano obserwacji oraz analiz niepokojących zjawisk i w dalszym ciągu reagowano niezwłocznie, obniżając szacunki wszędzie tam, gdzie statystyki pokazywały jakiekolwiek nieprawidłowości. Do podnoszenia zaś wskazanych wartości przystąpiono bardzo ostrożnie dopiero w 1938 roku [12, s. 9; 13, s. 11; 14, s. 12-13].

Podsumowanie. Reasumując, zauważyć należy, iż w analizowanym okresie na skutek braku wyobraźni, czy wręcz błędów w ocenie perspektyw rozwoju popełnionych tuż przed wybuchem światowego kryzysu gospodarczego przez kierownictwo Powszechnego Zakładu Ubezpieczeń Wzajemnych doszło do kumulacji niekorzystnych zjawisk, których skutki mogły być katastrofalne zarówno dla samego ubezpieczyciela, jak i dla jego klientów. Można zaryzykować stwierdzenie, iż gdyby do podobnych nietrafionych decyzji doszło $\mathrm{w}$ łonie prywatnego podmiotu, to $\mathrm{w}$ połączeniu ze wskazanymi czynnikami mogłoby to doprowadzić nawet do upadku zakładu. Jednak ze względu na fakt, iż mieliśmy do czynienia $\mathrm{z}$ faktycznym monopolistą na rynku ubezpieczeń nieruchomości od pożarów, który cieszył się ochroną i korzystał z opieki władz państwowych, wzorujących się w tym względzie na interwencjonistycznej polityce gospodarczej Zachodu, udało mu się przetrwać.

Drugim zjawiskiem, na które warto zwrócić uwagę, jest nadzwyczaj korzystne środowisko dla działalności przestępców ubezpieczeniowych wytworzone również na skutek błędów popełnionych przez publicznego ubezpieczyciela. Splot tych chybionych decyzji i niekorzystnych zjawisk ułatwił wyłudzanie odszkodowań. Dlatego mając świadomość, iż jest to teza dość śmiała trzeba podsumować niniejsze rozważania konkluzją brzmiącą tak, że zakład poświecił wiele lat, środków i wysiłków na walkę ze skutkami własnych błędów, które w innych warunkach mogłyby zostać skorygowane i naprawione o wiele mniejszym nakładem zasobów własnych.

Jednocześnie warto w tym miejscu podkreślić, iż mimo korzystnych zmian w technologii budowy nieruchomości, jakie obserwujemy w analizowanym okresie i wbrew zamierzeniom ubezpieczycieli, wspierających ogniotrwałą technikę wznoszenia 
budowli nie udało się zmniejszyć liczby pożarów, przeciwnie - wzrosła ona i to znacznie. Prowadzi nas to do jednoznacznego stwierdzenia, iż to czynnik ludzki wywierał największy wpływ na ilość pożarów w okresie wielkiego kryzysu gospodarczego.

\section{Bibliografia:}

1. Kostrowicka I., Landau Z., Tomaszewski J., Historia gospodarcza Polski XIX i XX wieku, Warszawa 1984.

2. Orlicki M., Ubezpieczenia obowiązkowe, Warszawa 2011.

3. Sprawozdanie rachunkowe Polskiej Dyrekcji Ubezpieczeń Wzajemnych za rok 1921, Warszawa 1922.

4. Sprawozdanie Polskiej Dyrekcji Ubezpieczeń Wzajemnych za lata 1923-1924, Warszawa 1925.

5. Sprawozdanie rachunkowe Powszechnego Zakładu Ubezpieczeń Wzajemnych za rok 1929, Warszawa 1930.

6. Sprawozdanie rachunkowe Powszechnego Zakładu Ubezpieczeń Wzajemnych za rok 1930, Warszawa 1931.

7. Sprawozdanie rachunkowe Powszechnego Zakładu Ubezpieczeń Wzajemnych za rok 1931, Warszawa 1932.

8. Sprawozdanie rachunkowe Powszechnego Zakładu Ubezpieczeń Wzajemnych za rok 1932, Warszawa 1933.

9. Sprawozdanie rachunkowe Powszechnego Zakładu Ubezpieczeń Wzajemnych za rok 1933, Warszawa 1934.

10. Sprawozdanie rachunkowe Powszechnego Zakładu Ubezpieczeń Wzajemnych za rok 1934, Warszawa 1935.

11. Sprawozdanie rachunkowe Powszechnego Zakładu Ubezpieczeń Wzajemnych za rok 1935, Warszawa 1936.

12. Sprawozdanie rachunkowe Powszechnego Zakładu Ubezpieczeń Wzajemnych za rok 1936, Warszawa 1937.

13. Sprawozdanie rachunkowe Powszechnego Zakładu Ubezpieczeń Wzajemnych za rok 1937, Warszawa 1938.

14. Sprawozdanie rachunkowe Powszechnego Zakładu Ubezpieczeń Wzajemnych za rok 1938, Warszawa 1939.

15. Sprawozdanie statystyczne Dyrekcji Przymusowych i Dobrowolnych Ubezpieczeń od ognia za rok 1931, Warszawa 1932.

16. Szczęśniak M., Zarys dziejów ubezpieczeń na ziemiach polskich, Warszawa 2003.

(C) Bednaruk W., 2018 